\title{
Lung Cancer Pathologic Distant Metastasis TNM Finding v7
}

National Cancer Institute

\section{Source}

National Cancer Institute. Lung Cancer Pathologic Distant Metastasis TNM Finding v7. NCI Thesaurus. Code C88878.

A pathologic finding about one or more characteristics of lung cancer, following the rules of the TNM AJCC v7 classification system as they pertain to distant metastases. There is no pathologic M0 for lung cancer. (from AJCC 7th Ed.) 